ISSN : 2550-0198

\title{
MENGUASAI SPEAKING SKILL BAHASA INGGRIS DENGAN KONSEP ENGLISH DAY BAGI GURU DAN KARYAWAN DI SMA ISLAM TERPADU FADHILAH PEKANBARU
}

\author{
Wandi Syahfutra*, Siti Niah \\ Prodi Pendidikan Bahasa Inggris, Fakultas Keguruan dan Ilmu Pendidikan \\ Universitas Muhammadiyah Riau \\ *Email: wandisyahfutra@umri.ac.id
}

\begin{abstract}
Abstrak
Dalam upaya peningkatan kualitas sumber daya manusia didunia pendidikan, penguasaan bahasa asing, terutama bahasa Inggris, merupakan suatu hal yang sangat penting. Hal ini didasari atas bahasa Inggris adalah bahasa global yang digunakan pada era saat ini. Berdasarkan analisa yang telah dilakukan, penerapan penggunaan bahasa Inggris oleh guru dan karyawab di SMA IT Fadhilah belum terlaksana dengan dengan baik. Atas dasar analisa tersebut maka diadakanlah pelatihan "Menguasai Speaking Skill Bahasa Inggris dengan Konsep English Day bagi Guru dan Karyawan SMA IT Fadhilah Pekanbaru” yang bertujuan untuk meningkatkan kemampuan berbahasa Inggris guru dan karyawan. English day bisa menjadi program yang tepat bagi guru, siswa dan karyawan ditingkat sekolah maupun universitas. English day adalah program untuk melatih dan membiasakan penggunaan Bahasa Inggris dalam kegiatan sehari-hari. Dimana mengharuskan para peserta untuk berbahasa Inggris dalam waktu yang telah disepakati. Para peserta tidak boleh menggunakan Bahasa selain bahasa Inggris pada waktu English day berlangsung. Adapun metode yang digunakan dalam kegiatan pelatihan ini adalah metode ceramah, diskusi, dan praktek. Adapun hasil Hasil kegiatan pengabdian kepada masyarakat ini mendapatkan sambutan yang sangat positif dari pihak mitra yakni Sekolah Menengah Atas Islam Terpadu Fadhilah Pekanbaru karena program ini sesuai dengan kebutuhan mereka. Bentuk sambutan yang sangat positif tersebut adalah terlihat dari partisipasi seluruh peserta pelatihan baik guru maupun karyawan yang hadir pada pelatihan tersebut sangat aktif dalam mengikuti seluruh proses kegiatan.
\end{abstract}

Kata kunci: Bahasa Inggris, English Day, SMA IT Fadhilah

\section{PENDAHULUAN}

Salah satu aspek yang penting dalam kehidupan manusia adalah pendidikan. Dalam pendidikan manusia dapat belajar banyak hal dan pengetahuan untuk menjawab tuntutan zaman dan arus globalisasi yang kian menantang. Agar dapat memenuhi tuntutan dan perubahan tersebut setiap pribadi diminta menyiapkan diri sedini mungkin yang diproses melalui tahap-tahap pendidikan. Maju mundurnya dunia pendidikan sangat tergantung pada pengelolaan pendidikan, tenaga pengajar, peserta didik dan sarana yang digunakan dalam Pendidikan tersebut.

Sebagai penunjang alat komunikasi yang salah satunya di bisang pendidikan, manusia membutuhkan sarana yaitu bahasa 
ISSN : 2550-0198

sebagai sarana paling utama. Bahasa mempunyai pengaruh yang cukup besar dalam kehidupan manusia. Bahasa Inggris merupakan salah satu Bahasa Internasional yang dibutuhkan dalam berkomunikasi dan mempunyai peranan yang sangat penting dalam menjalin hubungan dengan bangsa lainnya di era ini.

Era informasi sekarang, Bahasa Inggris merupakan Bahasa global dalam semua lini kehidupan; sekolah, perdagangan, politik dan kepariwisataan. Oleh Karena itu, dibutuhkan pembiasaan pemakaian Bahasa Inggris dalam kegiatan seharihari.

Seperti halnya sekolah-sekolah Menengah Pertama lain di kota Pekanbaru dan kota-kota besar di Indonesia, SMA IT Fadhilah Pekanbaru juga berbenah diri secara terus-menerus dalam rangka meningkatkan mutu pengajaran dan pengelolaan sebagai upaya untuk menuju sekolah yang mampu bersaing secara nasional maupun internasional nantinya.

Pelatihan Bahasa Inggris "Menguasai Speaking Skill Bahasa Inggris dengan Konsep English Day bagi Guru dan Karyawan SMA IT Fadhilah Pekanbaru", merupakan salah satu upaya yang dapat dilakukan untuk meningkatkan kemampuan penguasaan bahasa Inggris bagi guru dan karyawan.

Berkaitan dengan komitmen SMA IT Fadhilah Pekanbaru untuk meningkatkan kemampuan bahasa Inggris bagi para guru dan karyawan, bantuan penanganan yang terencana dan terprogram kiranya sangat dibutuhkan. Untuk itulah program ini dirancang sebagai upaya untuk memberikan sumbangan yang bermanfaat bagi masyarakat, terutama bagi dunia pendidikan. Pelatihan Bahasa Inggris "Menguasai Speaking Skill Bahasa Inggris dengan Konsep English Day bagi Guru dan Karyawan SMA IT Fadhilah Pekanbaru" ini diharapkan dapat membantu para guru dan karyawan termotivasi dan merasa senang dalam belajar bahasa Inggris sehingga guru dan karyawan SMA IT Fadhilah Pekanbaru mampu menggunakan bahasa Inggris dalam keseharian dan pendidikan.

English day bisa menjadi program yang tepat bagi guru, siswa dan karyawan, serta karyawan ditingkat sekolah maupun universitas. English day adalah program untuk melatih dan membiasakan penggunaan Bahasa Inggris dalam kegiatan seharihari. Dimana mengharuskan para peserta untuk berbahasa Inggris dalam waktu yang telah disepakati. Para peserta tidak boleh menggunakan Bahasa lain pada waktu English day berlangsung.

Secara teoritis, program ini dapat memberikan banyak manfaat. Program ini dapat melatih pembicara mempunyai keberanian berbicara, penguasaan vocabulary, sama halnya pembelajaran yang diadakan di Pare yang dikenal dengan 'Kampung Inggris' dengan menggabungkan antara kedisiplinan dan kemahiran berbahasa Inggris dengan suasana yang menyenangkan, dimana selama peserta berada dilokasi tersebut terlatih untuk berbahasa Inggris karena hanya Bahasa Inggris lah yang digunakan masyarakat kampung tersebut selama peserta berada disana.

Maka berdasarkan data tersebut diatas bisa diketahui bahwa English 
Day sangat membantu siapa saja yang ingin memperlancar dan menambah kemampuan berbahasa Inggrisnya. Dengan menciptakan suasana lingkungan yang mendukung kelancaran kegiatan ini, misalnya mendatangkan native speaker ke sekolah sekali dalam sebulan agar bertambah semangat untuk mempelajari Bahasa Inggris.

Adapun system English Day, terbilang mudah dan simpel untuk diterapkan, adapun langkahlangkahnya adalah sebagai berikut:

Buatlah kesepakatan dengan peserta English Day pada hari apa akan disepakati sebagai hari berbahasa Inggris. Untuk pertama ambillah dua hari dalam satu minggu.

Setiap peserta diharapkan mengenakan pin English Day pada hari yang telah ditentukan, di pin ini ada tulisan yang bisa mengingatkan peserta untuk tidak menggunakan Bahasa yang lain selain Bahasa Inggris selama mengenakan English Day berlangsung. Salah satu contoh tulisan di pin tersebut: "Speak English, Please!". Jadi, selama waktu penggunaan pin dipakai setiap peserta diwajibkan berbahasa Inggris, seandainya ada peserta yang tidak menggunakan Bahasa Inggris selama waktu yang ditentukan akan dikenakan hukuman dengan bentuk yang telah disepakati, dan juga akan ada reward bagi peserta yang menyelesaikan program tersebut dengan baik.

Satu kali dalam seminggu akan ada kelas belajar Bahasa Inggris yang akan dikelola oleh guru-guru Bahasa Inggris, jika memungkinkan akan didatangkan native speaker sekali dalam sebulan, agar peserta English Day termotivasi dalam mempelajari Bahasa Inggris.

English Day adalah program yang sangat menyenangkan yang mana tidak akan lepas dari canda tawa. Pada awalnya melihat dan mendengarkan pengucapan Bahasa Inggris teman anda mungkin terasa aneh, canggung dan lain-lain, tapi jika sudah terbiasa juga akan terasa sangat menyenangkan. Akan terasa sangat menyenangkan belajar Bahasa Inggris dengan rekan dilingkungan kerja dan sesama peserta dapat saling mengoreksi kesalahan.

Berdasarkan penjelasan diatas, penerapan konsep English Day yang menyenangkan bisa memberikan dampak yang sangat signifikan untuk penguasaan speaking dimana setiap peserta sangat termotivasi dan merasa senang belajar bahasa Inggris sehingga mereka bisa dengan mudah menguasai bahasa Inggris.

\section{METODE PENGABDIAN}

Metode yang digunakan dalam kegiatan pelatihan ini adalah metode ceramah, diskusi, dan konsep English day. 1) Metode Ceramah digunakan untuk menyampaikan materi secara rinci tentang penguasaan skil speaking bahasa Inggris, 2) Metode Diskusi digunakan untuk mengakomodasi pertanyaan atau masukan tentang topik pada materi yang telah disampaikan. 3) Metode Cooperative Learning diterapkan untuk melihat keaktifan guru dan karyawan dalam menggunakan bahasa Inggris.

Kegiatan PPM diawali dengan perkenalan antara Tim pelaksana 
ISSN : 2550-0198

dengan peserta pelatihan yaitu guru bahasa Inggris dan wali murid siswa SMA IT Fadhilah Pekanbaru, yang dilanjutkan dengan pengenalan materi pelatihan kepada peserta latihan. Selanjutnya melakukan kegiatan proses pelatihan bahasa Inggris dengan konsep English day, diakhiri dengan review singkat, diskusi, dan praktek bagi peserta pelatihan.

\section{HASIL DAN PEMBAHASAN}

Hasil kegiatan pengabdian kepada masyarakat ini mendapatkan sambutan yang sangat positif dari pihak mitra yakni SMA Islam Terpadu Fadhilah Pekanbaru karena program ini sesuai dengan kebutuhan mereka. Bentuk sambutan yang sangat positif tersebut adalah terlihat dari partisipasi seluruh peserta pelatihan baik guru maupun karyawan yang hadir pada pelatihan tersebut sangat aktif dalam mengikuti seluruh proses kegiatan. Antusiame ini juga tergambar dari banyaknya peserta yang ikut berpartisipasi ketika diminta maju kedepan para peserta lainnya untuk mempraktekkan metode pembelajaran bahasa Inggris yang telah diberikan dengan konsep English day.

Seluruh peserta pelatihan memiliki motivasi yang tinggi yaitu dengan sangat antusianya mereka dalam kegiatan pelatihan. Hal tersebut mengindikasikan bahwa adanya kesadaran para peserta pelatihan dalam memahami pentingnya menguasai Bahasa Inggris pada era saat ini. Peningkatan kemampuan guru dan karyawan terhadap penguasaan skil bahasa Inggris terutama di era modern saat ini dimulai dari kelompok belajar disekolah dan menciptakan lingkungan berbahasa iti sendiri. Hal ini dikarenakan bahasa Inggris merupakan skil yang harus dimiliki setiap orang untuk dapat memahami berbagai bidang keilmuan serta teknologi informasi agar mampu bersaing.

Upaya yang dilakukan pihak SMA IT Fadhilah selama ini agar para guru dan karyawan mampu berbahasa Inggris dengan baik salah satunya adalah dengan menerapkan 3 bahasa (Inggris, Arab, dan Indonesia) dalam seminggu tapi belum terlalu efektif. Peningkatan pemahaman tentang bahasa Inggris bagi sekolah adalah dengan cara meningkatkan kualitas guru. Untuk meningkatkan penguasaan Bahasa Inggris guru dan karyawan tersebut maka salah satu cara adalah melalui program English Day.

Berdasarkan hasil yang didapat dari kegiatan pengabdian pada masyarakat (PPM) yang telah dipaparkan, bahwa kegiatan pengabdian ini mendapat respon yang sangat baik dari para peserta. Guru bahasa Inggris dan karyawan SMA IT Fadhilah Pekanbaru khususnya yang mayoritas tidak memiliki latar belakang pendidikan bahasa Inggris juga ikut andil secara aktif dalam setiap sesi kegiatan.

Kegiatan yang di ikuti oleh peserta pengabdian berjalan dengan baik meskipun ada beberapa peserta yang tidak memiliki latar belakang pendidikan bahasa Inggris, namun kerjasama yang baik dan proaktif diantara para peserta yang sangat antusias mempraktekkan kemampuannya dengan bersungguhsungguh mempraktekkan cara bahasa Inggris di depan peserta lain dengan bekal materi yang sudah diberikan 
ISSN : 2550-0198

pada pelatihan tersebut, maka hal tersebut dapat menyelesaikan masalah yang dihadapi selama proses berlangsung. Keberhasilan kegiatan pengabdian ini terlihat dari adanya kemauan atau kesungguhan yang tinggi yang ditunjukkan oleh peserta melalui kegiatan selama proses berlangsung. Hal ini menunjukkan bahwa mereka merasakan manfaat dari adanya kegiatan pengabdian ini sehingga mereka menganggap penting untuk menguasai bahasa Inggris.

\section{SIMPULAN}

Upaya untuk meningkatkan kualitas sumber daya manusia di era modern merupakan suatu keniscayaan karena ilmu pengetahuan dan teknologi semakin maju maka seiring itu pula sumber daya manusia perlu ditingkatkan. Penguasaan bahasa asing, terutama bahasa Inggris, merupakan suatu hal yang sangat penting. Kemampuan bahasa Inggris dapat mudah dikuasai apabila selalu dipraktekkan dalam kesehariannya sehingga semakin mahir kemampuan berbahasa Inggris maka semakin banyak pula ilmu dan teknologi informasi dapat dipahami dan dikuasai.

Pelatihan "Menguasai Speaking Skill Bahasa Inggris dengan Konsep English Day Bagi Guru dan Karyawan SMA IT Fadhilah Pekanbaru" merupakan salah satu upaya yang dapat dilakukan untuk meningkatkan kemampuan berbahasa Inggris bagi guru dan karyawan. Materi pelatihan yang diberikan mencakup teknik-teknik penguasaan English speaking skill melalui program English day, sehingga guru dan karyawan dapat memahami dan mempraktekkan bahasa Inggris sebagai bahasa global yang banyak dipakai dalam berbagai bidang keilmuan, teknologi, dan juga alat utama untuk berkomunikasi.

Kegiatan yang dilaksanakan diikuti oleh guru bahasa Inggris dan karyawan SMA IT Fadhilah Pekanbaru. Para peserta pelatihan sangat antusias dalam mengikuti pelatihan tersebut, hal ini dibuktikan dengan banyaknya peserta yang ingin mencoba mempraktekkan secara langsung konsep English day di depan peserta lain, selain itu hampir seluruh peserta aktif dalam sesi diskusi.

\section{UCAPAN TERIMAKASIH}
Ucapan terimakasih diberikan kepada Bapak/Ibu/Sdr atas kesediannya membantu terlaksananya kegiatan Pengabdian Pada Masyarakat (PPM) yaitu kepada:

1. Universitas Muhammadiyah Riau sebagai penyandang dana Pengabdian kepada Masyarakat

2. Dekan Fakultas Keguruan dan Ilmu Pendidikan UMRI

3. Ketua Lembaga Penelitian dan Pengabdian Masyarakat (LPPM) UMRI

4. Kepala Sekolah Menengah Atas Islam Terpadu Fadhilah Pekanbaru

5. Pihak-pihak yang tidak dapat kami sebutkan namanya yang telah banyak membantu terlaksananya PPM.

\section{DAFTAR PUSTAKA}

[1] Brown, H. Douglas. 2001. Teaching by Principles: An 
Interactive Approach to

Language Pedagogy (2nd ed).

New York: Pearson Education Company.

[2] Stern H. H. 1991. Fundamental Concepts of Language Teaching. USA. University Press

[3] Bambang. 2012. sambut Program English Day, Guru Dibekali Daily Conversation. (Online), (http://www.putraindonesiamal ang.or.id/sambut-programenglish-day-guru-dibekalidaily-conversation.html, diakses tanggal 15 Mei 2017

[4] Bambang Yudi, C. 1997. Pengajaran Bahasa Inggris. Malang: Penerbit IKIP Malang.

[5] Osterlund, C. 2011. Fun with Speaking. Oregon State University Extension Service Gilliam Country 